\title{
Г.А. Барсукова
}

\section{ПРОФЕССИОНАЛЬНАЯ ПОДГОТОВКА БИБЛИОТЕЧНЫХ СПЕЦИАЛИСТОВ. ВЗАИМОДЕЙСТВИЕ ВУЗА И БИБЛИОТЕКИ}

\begin{abstract}
Рассматривается опыт взаимодействия вузовских библиотек города Барнаула и факультета информационных ресурсов и дизайна Алтайской государственной академии культуры и искусств на примере Научно-технической библиотеки Алтайского государственного технического университета им. И.И. Ползунова.

Ключевые слова: подготовка специалистов, библиотечные специалисты, профессиональная подготовка, профессиональная адаптация, конкурентоспособность, вузовские библиотеки, опыт работы.
\end{abstract}

В XXI в. проблема образования является одной из приоритетных во всем мире, так как определяет будущее каждого человека.

Образование занимает важное место и в сфере культуры, по сути, являясь той основой, которая обеспечивает ее стабильность, достижения, постоянный приток новых творческих кадров, воспитанных на лучших отечественных традициях. В последнее время наблюдается интерес к проблеме подготовки библиотекарей в условиях высшей школы.

Информационные процессы в обществе определяют и темпы развития библиотек. Полным ходом идет их информатизация: оснащение современной техникой, внедрение процессов электронного заказа и электронной книговыдачи, пополнение фондов электронными информационными ресурсами. Библиотеки нуждаются в профессионалах и требуют от учебных заведений соответствующего уровня подготовки студентов. Вузы готовят библиотечноинформационных специалистов, делая акцент на формировании компьютерной грамотности, умении работать с новыми информационными технологиями, вычислительными сетями, мультимедийными системами. Они ориентируются не только на повышение качества профессиональной подготовки, но и на конкурентоспособность выпускников на рынке труда.

Для того чтобы выпускники отвечали ожиданиям библиотек, важна соответствующая методика их подготовки. Какими средствами и методами сегодня можно воспитать профессионала, готового к творческой работе в области библиотечных и информационных услуг? Назревшие проблемы в сфере подготовки библиотечных кадров можно решить только с помощью консолидации разрозненных усилий библиотечной практики, науки и образования, активного воплощения оригинальных идей и творческих дерзаний [1. С. 40].

Учебно-методическая база подготовки студентов не ограничивается только программами, учебниками и курсами лекций. Неотъемлемыми составляющими учебного процесса являются курсовые и дипломные работы, научно-исследовательская работа студентов, а также учебная и производственная практика в базовых учреждениях культуры и образования. В библиотеках студенты проходят ознакомительную, учебную, производственную, преддипломную практику. 
Производственная практика является одной из основ образовательного процесса. За многие годы существования вузов культуры накоплен значительный опыт по организации производственной практики будущих библиотекарей. Социальное партнерство между вузом и библиотеками выступает как важнейшее условие повышения качества подготовки специалистов, представляя собой инструмент мониторинга, дающий возможность оценить соответствие качества подготовки выпускников вуза требованиям работодателей и выбрать оптимальные пути совершенствования образовательных программ [2. C. 31].

Сложился особый круг партнеров, являющихся традиционными базами практики студентов библиотечных факультетов. Подготовкой специалистов широкого профиля, умеющих квалифицированно осуществлять основные библиотечные и информационно-библиографические процессы и способных специализироваться на любом рабочем месте, в любой библиотеке, занимается Алтайская государственная академия культуры и искусств (АГАКИ). Вузовские библиотеки Барнаула, в частности научнотехническая библиотека Алтайского государственного технического университета (НТБ АлтГТУ), традиционно служат основными базами производственной практики студентов факультета информационных ресурсов и дизайна АГАКИ.

Задачами студентов во время прохождения производственной практики являются закрепление теоретических знаний, полученных в процессе обучения, и приобретение практических навыков в будущей профессиональной деятельности.

Сегодня ушла в прошлое система распределения молодых специалистов. Очень часто производственная практика становится для студентов не только поворотным моментом в позитивном понимании сущности библиотечной профессии, но и местом, куда они приходят работать после окончания вуза. Если взять для примера Научно-техническую библиотеку АлтГТУ, то в этом коллективе сегодня успешно работают 13 человек, которые во время обучения в вузе проходили практику на базе данной библиотеки. Они составляют седьмую часть коллектива библиотеки головного вуза, без учета филиалов.

Обучение, построенное на практической работе, повышает интерес студентов к своей будущей профессии, они по-другому оценивают знания, полученные при теоретическом освоении учебных курсов. Производственная практика позволяет студенту надежнее закрепить знания, полученные в аудитории. Критерием оценки его практической деятельности становится конкретный результат, полученный в процессе реализации своих знаний на соответствующем рабочем месте. Безусловно, все это предъявляет особые требования и к руководителям библиотечно-информационных учреждений. Работодатель становится активным участником образовательного процесса, он знаком с перечнем требований, предъявляемых к студенту, с теми задачами, которые тот должен решить в процессе прохождения практики, и результатом, к которому он должен прийти после ее окончания.

Сотрудничество между факультетом информационных ресурсов и дизайна АГАКИ и НТБ АлтГТУ продолжается уже много лет. Преподаватели рассматривают и учитывают предлагаемые сотрудниками библиотеки темы для 
дипломных работ, практическая часть которых основывается на результатах исследований, проводимых студентами на базе библиотеки.

На факультете разработаны программы производственной практики для студентов II, III, IV и V курсов. В программах обозначены цели и задачи практики, даны индивидуальные задания, которые должен выполнить студент в библиотеке. Это помогает сотруднику библиотеки определить характер работы, подготовить конкретный перечень заданий для студентов на время прохождения ими практики. Как правило, задания соотносятся с планами работы отделов библиотеки. Ежегодно библиотека принимает на производственную практику 10-12 студентов II-V курсов. Так, студенты II курса выполняют задания по изучению процесса формирования библиотечного фонда, по аналитико-синтетической переработке, работе со справочно-поисковым аппаратом. Соответственно, их наставниками на протяжении практики являются сотрудники отделов комплектования, научной обработки литературы и научно-библиографического отдела. Руководитель практики от библиотеки знакомит практикантов с организацией работы библиотеки в целом, с сотрудниками отделов, проводит ознакомительную экскурсию по структурным подразделениям. Непосредственно на рабочем месте студенты-практиканты выполняют ту же работу, что и сотрудники отдела. Их деятельность ежедневно контролирует заведующий отделом. Понимая значимость выполняемых заданий, получая поощрительную оценку своего труда, чувствуя доброжелательное к себе отношение, студенты с большой ответственностью относятся к выполняемой работе и на последующих курсах для прохождения очередной практики стремятся вернуться именно в эту же библиотеку. Руководство библиотеки охотно принимает хорошо зарекомендовавших себя, серьезных, ответственных студентов.

На III курсе студенты-практиканты выполняют задания по библиотечному обслуживанию пользователей в отделах обслуживания, знакомятся с организацией библиографической деятельности библиотеки, принимают участие в подготовке выставок, проведении Дня информации, Дня библиотеки на факультете/кафедре, других мероприятиях.

Во время прохождения методической практики на IV курсе студенты на деле применяют знания, полученные в вузе. Достаточно высокий уровень подготовки студентов в вузе позволяет им выполнять ответственные задания во время прохождения практики.

Завершает профессиональную подготовку библиотечных специалистов высшей квалификации производственная практика студентов V курса, в процессе которой студенты знакомятся с вопросами управления библиотекой. Студентам предоставляется возможность применить на практике методы стратегического планирования, организации, анализа и мотивации библиотечно-информационной деятельности.

Заслуживает внимания и преддипломная практика. Студентыдипломники в своих квалификационных работах используют материалы исследований, проводимых на базе библиотеки. Исследуются самые разные стороны библиотечной работы: обслуживание читателей, удовлетворенность предоставляемыми библиотечно-информационными услугами, реклама и др. Результаты этих исследований учитываются затем при планировании работы 
руководителями отделов библиотеки. Но для этого необходимо, чтобы тематика дипломных работ была соотнесена с социальным библиотечным заказом. А потому руководители практики в вузе и базовой библиотеке заранее согласовывают темы проводимых исследований.

Студенты, прошедшие так называемую «сквозную» практику, т. е. на протяжении всего периода обучения работающие в одной библиотеке, получают возможность глубже познакомиться со всеми технологическими процессами и операциями, начиная с комплектования фонда, записи читателя в библиотеку и заканчивая анализом организации работы библиотеки в целом. Они начинают ощущать себя частью большого слаженно работающего коллектива. Естественно, что кто-то из них затем выражает желание остаться работать в библиотеке. Опрос студентов, проходивших практику, подтверждает интерес к библиотеке как к потенциальному месту работы.

В библиотеке студент проходит практику в разных отделах, собирает материал к диплому, выполняет большой объем самостоятельных заданий. Теперь он уже знает, где и кем хочет работать [3. С. 346]. В современной библиотеке молодежь может получить возможность реализовать свои познания в области прикладных наук, совершенствуя, например, методику библиографического поиска или аналитико-синтетическую обработку документов. У этой категории наших потенциальных сотрудников нужно создавать необходимую мотивацию с момента их пребывания в библиотеке в качестве студента-практиканта.

Еще во время прохождения производственной практики студенты понимают, что сотрудникам небезразлично то, какой видят практиканты библиотеку. Это чувствуется и на защите практики, когда члены комиссии, в составе которой руководители библиотеки и отделов, помимо оценки деятельности практикантов, заинтересованно расспрашивают их о том, что понравилось, какие предложения по улучшению работы библиотеки у них появились. Обмен мнениями происходит при участии руководителя практики от АГАКИ.

В последние годы стало также доброй традицией проводить публичную защиту практики на факультете информационных ресурсов и дизайна Алтайской государственной академии культуры и искусств с приглашением руководителей практики от библиотек. На защите происходит обмен мнениями и впечатлениями между студентами, проходившими практику в библиотеках различных ведомств. Это дает возможность в будущем что-то корректировать в подготовке и проведении производственной практики как преподавателям, так и сотрудникам базовых библиотек.

Сотрудники библиотек приглашаются также на открытые занятия, проводимые со студентами IV курса, где они презентуют свои методические разработки.

Все это, несомненно, способствует укреплению контактов преподавателей и студентов вуза с библиотечной средой, с практиками библиотечного дела. Но прежде всего это помогает подготовке квалифицированных кадров для библиотек с учетом реально имеющихся потребностей.

Проблема подготовки библиотечных кадров активно обсуждается библиотечным сообществом на различных уровнях. На всех этапах профессионализации библиотечных кадров отмечается отсутствие налаженной взаимо- 
связи «вуз - работодатель». Учебно-методическим советом МГУКИ в 2013 г. принято консолидированное решение о правомерности инициирования вузовским педагогическим сообществом подготовки профессионального стандарта как компетентностной модели специалистов конкретной области деятельности, что позволит установить устойчивые связи между российской высшей библиотечной школой и реальной деятельностью современной библиотеки, обозначить потребности практики и квалификации кадров [4. С. 97].

\section{Лumepamypa}

1. Ловкова Т.Б. Современные проблемы подготовки библиотечных специалистов // Научные и технические библиотеки. 2006. № 6. С. 36-40.

2. Кудрина Е.Л. Повышение качества подготовки специалистов библиотечноинформационного профиля в контексте социального партнерства вуза с библиотеками региона // Научные и технические библиотеки. 2008. № 2. С. 31-36.

3. Сукиасян Э.Р. Библиотечное образование и библиотечная практика // Библиотечная профессия. Кадры. Непрерывное образование: сб. ст. и докл. М.: ФАИР-ПРЕСС, 2004. С. 343-350.

4. Клюев B.K. По каким учебникам, чему и кого готовить в бакалавриате // Библиография. 2013. № 1. C. 93-99.

Barsukova Galina A. Scientific and Technical library of Altai State Technical University (Barnaul, Russian Federation). E-mail: galina_barsukova@ mail.ru. DOI 10.17223/22220836/17/4

PROFESSIONAL TRAINING OF LIBRARIANS. THE INTERACTION OF THE UNIVERSITY AND THE LIBRARY

Key words: training, library specialists, training, professional adaptation, competitiveness, university libraries, work experience.

One of the ways to increase the competitiveness of graduates is to develop their practical skills. That can be achieved only through joint efforts of the university and its partners, who are the traditional base for practical training of students. Universities of culture have considerable experience in organizing practical training for future librarians gained for many years of their existence.

University libraries in Barnaul and the scientific and technical library of Altai State Technical University (AltSTU) in particular traditionally are the main bases for practical training of students of the Faculty of Information Resources and Design of Altai State Academy of Culture and Arts (ASACA).

At the Faculty the programs of practical training for students of the second, third, fourth, and fifth year have been developed. Goals and objectives of the training, individual tasks to be performed by a student in the library are worked out and given in the programs. It helps the head of the practical training to determine the kind of work, to prepare a specific list of tasks for the students. Due to the fact that the library cooperates with ASACA in this direction for many years, tasks relate to plans of departments. Every year the library takes 10-12 students of the second, third, fourth, and fifth year for practical training. A high enough level of students' training allows them to perform important tasks at their workplace. They often tend to return to our library for the next practical training period.

Students who have passed the so-called "pass-through" practice, i.e. working in the same library throughout the whole training period, have the opportunity to learn all the processes and operations more deeply, starting with the library collection development, readers' registration and with an analysis of the organization of the library work as a whole.

During the practical training students realize significance and necessity of their work. They understand that library staff is care of trainees' impression of the library.

The presentation of practical training results is necessary. The board consists of the library director, the head of practical training of ASACA, heads of the departments in which students worked. During presentations in addition to evaluation of the trainees work, the important point is exchange of opinions about things they liked and exchange of suggestions for improvement of the library work.

In recent years it has become a tradition to hold public presentations of practical training results at the Faculty of Information Resources and Design to heads of practical training of different libraries. 
Library staff is also invited to the open sessions conducted by the forth-year students, where they present their methodological developments.

Undoubtedly it helps to strengthen the contacts of teachers and students of the university with the library environment, with the practices of librarianship. But above all, it helps to train the qualified personnel for libraries with the actual current needs.

\section{References}

1. Lovkova T.B. Sovremennye problemy podgotovki bibliotechnykh spetsialistov [Modern problems of librarians' educations]. Nauchnye i tekhnicheskie biblioteki - Scientific and Technical Libraries, 2006, no. 6, pp. 36-40.

2. Kudrina E.L. Povyshenie kachestva podgotovki spetsialistov bibliotechno-informatsionnogo profilya v kontekste sotsial'nogo partnerstva vuza s bibliotekami regiona [Improving the quality of librarian education in the context of social partnership between the university and regional libraries].

Nauchnye i tekhnicheskie biblioteki - Scientific and Technical Libraries, 2008, no. 2, pp. 31-36. 3. Sukiasyan E.R. Bibliotechnoe obrazovanie i bibliotechnaya praktika [Library Education and Practice]. In: Sukiasyan E.R. (ed.) Bibliotechnaya professiya. Kadry. Nepreryvnoe obrazovanie [Librarianship. People. Life-long education]. Moscow: FAIR-PRESS Publ., 2004, pp. 343-350.

4. Klyuev V.K. Po kakim uchebnikam, chemu i kogo gotovit' v bakalavriate [Bachelor programs: what to teach, whom to teach and what textbooks to use]. Bibliografiya, 2013, no. 1, pp. 93-99. 